\title{
The Changing Concept of Sanitation Management in Kumbh Mela and Further Challenges
}

\author{
Ashok Kumar Kanaujiya ${ }^{1}$, Dr. Vineet Tiwari ${ }^{2}$ \\ ${ }^{1}$ M. Tech, Research Scholar, Department of Management Studies, Indian Institute of Information Technology Allahabad, Prayagraj, \\ Uttar Pradesh, India \\ rwm2021003[at]iiita.ac.in \\ ${ }^{2}$ Ph. D., Assistant Professor, Department of Management Studies, Indian Institute of Information Technology Allahabad, Prayagraj, \\ Uttar Pradesh, India \\ vineet.tiwari[at]iiita.ac.in
}

\begin{abstract}
Purpose of Review: The Kumbh Mela is considered to be one of the largest and magnificent religious gatherings on Earth. The expectation of pilgrims have enhanced regarding sanitation management and due to evolvement of new pandemic like COVID - 19 it became pertinent to focus more and very minutely during organization of Kumbh Mela. This paper emphasis on the comparative study of sanitation management during Kumbh Mela 2019 and earlier Kumbh Melas. It also focuses on Government's efforts to effectively implement the strategies of sanitation management with innovative approaches. It also aims to identify the shortcomings which are very important and suggestions will be provided to be helpful for next Kumbh Mela. Recent findings: The role of sanitation management has been increased enormously and the number of people participating Kumbh Mela are increasing. The great challenge is to clean the area after completion of Kumbh Mela and prevent the spreading of the infectious disease and effective disposal of garbage and sludge. Summary: Kumbh Mela is a Hindu religious gathering at the banks of India's river. The large number of pilgrims assemble and has the potential of creating large amount of garbage and sludge. This could affect the sanitation system of city and may spread the epidemic diseases and also overwhelm the healthcare system.
\end{abstract}

Keywords: Kumbh Mela; Mass gathering;; Sanitation management.

\section{Introduction}

The Kumbh Mela is considered to be one of the largest and magnificent religious gatherings on earth. Every twelve years, a millions of people turn up for the Kumbh Mela for more than a month of festivities. The same is witnessed in Ardh Kumbh Mela, which takes place every six years. Millions of people from across the world travel to the city of Haridwar, Prayagraj, Nasik and Ujjain during this holy month to take a dip in the river. Devotees consider this opportunity to bathe in the river to be an extremely holy moment in their lives. The rivers are believed to be flowing with Amrit ("the nectar of immortality") during this auspicious month of the Kumbh Mela. Each place hosts a Mela every twelve years in an astrologically determined, cyclic sequence that enables the Kumbh Mela to occur in approximately three - year intervals. On December 7th, 2017, the Intergovernmental Committee for the Safeguarding of Intangible Cultural Heritage under UNESCO recognized Kumbh Mela, the largest congregation of pilgrims on earth, as an 'Intangible Cultural Heritage of Humanity' [1]. The Kumbh Mela provides a broad perspective of the entire range of varied thoughts and practices of the Hindu way of life. A large number of visitors to the Kumbh Mela are women and youth, whose active presence greatly enhances the color, energy, and vitality of this vast gathering of humanity. Across denominations and sects, their numbers have been exponentially growing over the years, be they lay kalpvasis (lay visitors) or kathavachaks (preachers).

The Hindus believe that four drops of Amrit landed on four locations of the earth where the Kumbh Mela is celebrated today [26]. In Hindu mythology, it is said that the Gods sought this nectar of immortality hidden deep in the ocean of milk. When they decided to churn it out of the ocean, Lord Vishnu obliged by assuming the shape of a tortoise whose shell became the base on which the churn could be placed. The Himalayan Mount 'Mandara' was used as the churning stick, while the serpent 'Vasuki' became the rope with which the churning would be done. However, to get the nectar, the Gods required the help of the asuras (or, antiGods) who would pull one end of the churning rope while the Gods pulled the other. As they exerted themselves, the Kumbh (i. e., the pot) gradually rose to the surface of the ocean. The asuras, seeing a golden opportunity, readily seized the Kumbh. In this moment of crisis, Lord Vishnu came to the rescue of Gods; assuming the form of an enchantress named Mohini, he was successful in deluding the asuras to hand him the Kumbh, following which it was delivered to the Gods. As the Gods left with the holy pot, four drops are believed to have fallen from it and those places Kumbh Mela is organized.

Based on the Administrative reports submitted by the respective Mela officer of Kumbh and Ardh Kumbh Mela in year 1989, 1994 - 95, 2001, 2007, 2013 and 2019, the numbers of pilgrims participated in Kumbh and Ardh Kumbh Mela are plotted on graph [Fig.1 and Fig.2]. It shows the rapid increasing pattern of inflow of pilgrims in Kumbh and Ardh Kumbh Mela in last two decades. 


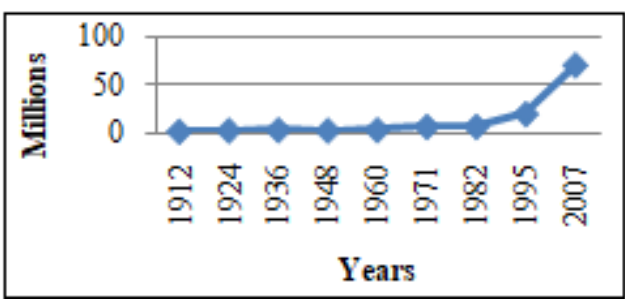

Figure 1: Pilgrims participation in Kumbh Mela

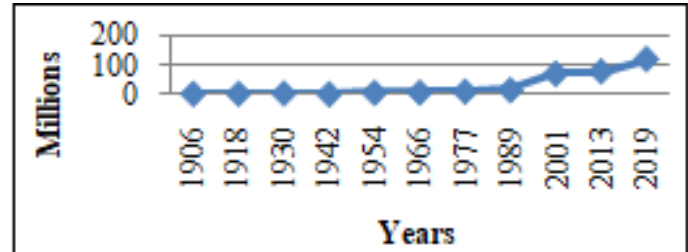

Figure 2: Pilgrims participation in Ardh Kumbh Mela

Hinduism is an ancient religion followed by over 1.1 billion people worldwide. This constitutes more than $15.1 \%$ of humanity [2]. Both foreign and Indian pilgrimage participate the Kumbh Mela to attain the spiritual connectivity (devotion) and spiritual knowledge attainment from saints, sadhus and Akharas. . They are involved in early morning bath in the river, prayers, yoga (meditation), serving to self and others and listening the saints during spiritual discourse. They involve in religious gathering during spiritual discourses that were frequently delivered by various saints, such as sadhus (holy men) [3]. It is established that the religious mass gatherings attract people globally and there is always a health risk like spreading of infectious and communicable diseases due to international connectivity etc. The Country specific diseases have the potential to spread in another countries during movement of people from one place to another place during spiritual activities like Kumbh Mela, Hajj or any other sports activities like Olympic etc. [4, $5,23]$. There is potential for the international spread of middle east (ex. Saudi Arabia) respiratory syndrome association with mass gatherings and may cause pandemic like situations [6]. In mass gathering events respiratory, faecal - oral, vector - borne, blood - borne and sexual modes of disease transmissions have been identified [7]. To cater this problem there is need of specialized interdisciplinary approach to understand the health challenges and sanitation efforts that mass gathering events pose. Focus should be on potential risk assessment and coordinated efforts between departments for mitigation of problems [8]. The Lancet Conference on Mass Gathering Medicine in 2010 and the consequent Jeddah Declaration on Mass Gatherings highlighted that there is need to exchange knowledge, strategies, and collaborative approaches globally during mass gathering events [9]. The crowd movement dynamics are very different in different situations which also causes the possibilities of human stampedes. Although human stampedes are complex and multifactorial event but we need to make preparation accordingly [25].

\section{The Spiritual value of the Kumbh Mela}

Hindu festivals and rituals are determined on a scientific basis, generally accordance with planetary positions. Planets preceded living beings in the order of creation and are considered in Hinduism as divinity personified. In Hindu mythology, the nine incarnations (avtaras) of Lord Vishnu are supposed to correspond to the nine planets employed in astrological predictions. Jyotisha, as a part of Indian astrology, has its roots in Hindu mythology. As an integral part of the Vedas, Indian astrology is therefore known as Vedanga. References of Kumbh in generic terms one can find in NaaradiyaPuran (Mythology) 2/66/44, Shiv purana (Mythology) 1/12/22/23, whereas the specific astrological analysis explaining the event of Kumbh is available in the Barahpurana (Mythology) 1/71/47/48 and Brahma Purana (Mythology). For the pilgrims, a holy dip in the rivers and sangam (confluence of the Ganga, Yamuna and mystical Saraswati river) holds the utmost spiritual value [27]. They dip fully into the waters - once, twice, thrice- and then take the waters in their cupped hands to pour it again into the river as an offering to the Gods and to their ancestors. They make offerings of flowers and oil lamps, letting them float away with the currents of the water. In the evening, the pilgrims might come to the river bank for the Arti (lamp offerings) that is performed by pujaris (priests) who raise huge, oil lamps in salutation to the river. The rites are simple, but central to the spiritual experience of the Kumbh Mela. For those kalpavasis who have vowed to stay for a whole month, Ganga snan or a dip in the river is a rite they must perform once or twice a day. kalpavasis sit together in the evening with the saints and listen spiritual knowledge which createsassociative homophily [28]. Self - motivated pilgrims and kalpvasis under the guidance of Gurus and saints recorded strong affiliations with spiritual scale. Role of family and friends was noticeable associates to spirituality. Attainment of nirvana and serving the society had notable spiritual associations during the Kumbh Mela [24].

\section{History of sanitation efforts in Earlier Kumbh and Ardh Kumbh Mela}

Based on the Administrative reports submitted by the respective Mela officer of Kumbh and Ardh Kumbh Mela in year 1989, $1994-95,2001,2007$ and 2013, the traditional approach was adopted during Kumbh Mela 1989 for sanitation management. It was limited to toilets, urinals and digging of pits for garbage. Total Mela areas were around 1180 hectares and Mela area was divided into 09 sectors. For the pilgrims around 4180 toilets and 1526 urinal were constructed. Flag areas were identified around 321 where open defecation was prominent. For garbage disposal, 4980 pits were dug. During Ardh Kumbh Mela 1994 - 95, Mela areas were restricted to 980 hectare and divided into 09 sectors. Around 12024 toilets and 2051 urinals were constructed for the pilgrims. For garbage disposal 5629 pits were dug. During Kumbh Mela 2001, Mela areas was extended to 1200 hectares and divided into 11 sectors. Some focus was given sanitation management and around 21400 toilets and around 2020 urinals were made. Per day garbage disposal was around 20000 quintal and for this 5577 garbage pits were dug.48 flag areas identified. In Ardh Kumbh Mela 2007, Mela area was around 1620 hectares and divided into 11 sectors. Around 22770 toilets and 555 urinals were constructed and 38 flag areas and 3908 pits for garbage identified. In Kumbh Mela 2013, Mela area extended to around 2000 hectare and divided into 14 sectors. Around 35000 toilets constructed. Total garbage disposal during Mela was 10104.53 metric tons.

Volume 10 Issue 10, October 2021 www.ijsr.net 
During the Kumbh and Ardh Kumbh Mela Millions of people take bath in the river and do various religious activities near the river. There is huge settlement around river during the Mela which causes the discharge of various organic materials in river. This pollutes the groundwater which flows finally to river. It was observed that the overall pollution rates were high during Kumbh as compared to pre - and post - Kumbh analysis. Hardness and BOD (Biological oxygen demand) was found beyond the permissible limit [10]. Our concept of risk assessment is at an infant stage. we do preparations for the response activities during crisis while we should focus on risk assessment i.e. identifying risks at an early stage, characterize the risks and planning for risk reduction strategies. We need to focus on preparedness of health care and sanitation system by assessing the crowd [11]. During the Ardh Kumbh Mela 2007 there was lack of arrangement for disposal of untreated sewage and was higher level of bio - oxygen demand in the river and solid waste and dead animals were disposed in the pits dug in the river beds in Mela areas [12]. Waste /pollution management during the Kumbh Mela 2013 was dependent upon the waste management infrastructures/facilities available in Allahabad city while the infrastructure for waste management was not even sufficient for regular population of city. No additional arrangement in respect of waste management was planned/made for Kumbh Mela 2013 [16, 30]. Comptroller and Auditor General of India pointed that the Biochemical oxygen demand (BOD) level was above the permissible limit of testing points in the river Ganga and at the Sangam on the auspicious bathing dates [16]. The presence of millions of people bathing in a brief period raises the question of sanitation and for diseases like cholera and dysentery which infects the pilgrims and spread very rapidly due to close inhabitations in tent city of Mela [13]. In 2013, 46 protected bore wells with chlorination attached tanks, as well piped potable water through 20000 taps, 35000 toilets were provided to reduce the chance of water contamination but was not sufficient for the pilgrims lived in Mela area during Mela period [14, 29, 30]. The number of toilets have increased prominently after Mela 2013 for better sanitation management, cleanliness and prevent open defecation [fig.3]. It was found that there was lack of proper monitoring system which made ineffective uses of toilets. No any innovative approaches were thought of to make volunteer participation for awareness of clean river.

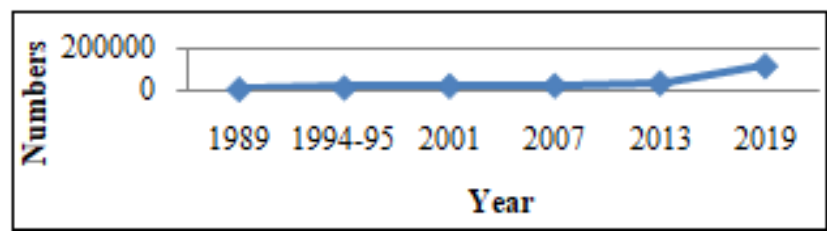

Figure 3: Number of Toilets installed during Kumbh Mela

\section{The overview of the Kumbh Mela 2019}

For the Kumbh Mela 2019, around 4200Crore Budget as sanctioned [17].683 projects conceptualized and executed during Kumbh Mela 2019. Around 5, 500 religious groups and organizations participated. There was Involvement of different Departments i. e. central, state, Indian Army, Indian Air force etc for execution of the projects like broadening and beautification of roads, Effective solid waste management, development of ROBs (Road over bridge) and
RUB (Road under bridge), Beautification of the city, Clean toilets for all development of traffic junctions, Electrification of all roads, drinking water at all the identified places, development of parks and green zone in the city. For Kumbh Mela 2019, a consolidated plan was developed for the development of city and Mela area to facilitate the pilgrims. Mela area was developed in around 3200 hectare in which public accommodation for more than 20000 pilgrims was made. Integrated command and control centre (ICCC) was established for crowd management through CCTV. Integrated Traffic Management System (ITMS) was developed for traffic control and regulation. For cultural and spiritual enhancement around 17.27 lakh sq. feet of street art undertaken under the Paint My city campaign. Kala Gram (creative village designed to showcase distinctive artwork with 13 dedicated pavilions developed under unique themes) and Sanskriti Gram (a mega structure with 17 different galleries exhibiting structures from different Indian civilizations etc.) were made.500 shuttle buses and 1000 e Rickshaws were deployed for pilgrims facilitation and 95 parking lots was developed for traffic control. According to the police department report, for security and safety purposes, 40 police stations, around 9000 police personnel, 40 watch towers, 4000 fire hydrants, 55 firefighting motorbikes and over 1000 CCTV cameras etc. were positioned. NDRF (National Disaster Relief Force) and SDRF (State Disaster Relief Force) were also deployed.

\section{Sanitation Management in Kumbh Mela 2019}

Kumbh Mela 2019 provided both a unique as well as a challenging prospect to demonstrate the commitment towards sanitation and public health. Earlier sanitation management was mostly focussed on the construction of toilets, in situ disposal of garbage and very little focus on odour management, volunteer participation and behavioural change and awareness of people. There was traditional system of monitoring which lacked the effective sanitation management that affected the healthcare system. Sanitation, infrastructure waste management plan, deployment of adequate dustbins and toilets, seamless and efficient waste evacuation system, round - the - clock smart monitoring of service delivery, adoption of environment friendly odour management strategy, large - scale training and sensitization workshops to transform village volunteers as well as behaviour change found supreme attention under the banner - 'Swachh Kumbh' during Kumbh Mela 2019. As per the Health and Family welfare department which was responsible for the sanitation and health management, daily waste generation was $200-500 \mathrm{MT} /$ day. Mela areas was divided into 20 sectors. More than 1.2 Lakh eco - friendly toilets were installed [15] [Fig.4, 5] in which total of 43, 512 community toilets were installed in the Mela area and 10, 534 at the bus stops, parking areas and across the approach roads for pilgrims. Around 36, 301 toilets were installed inside the spiritual and religious camps within the Mela area. Additionally, 17, 910 urinals with septic tanks ensured that there was no open urination in the Mela area. This number was the highest ever in the history of Kumbh Melas or any other mass gathering in India. Furthermore, over 6, 000 toilets were installed for providing better facilities to government camps and officials engaged in the Mela. There was first - time deployment of environment - friendly, disabled - friendly and easy to maintain prefabricated steel

Volume 10 Issue 10, October 2021 


\section{International Journal of Science and Research (IJSR)}

ISSN: 2319-7064

SJIF (2020): 7.803

toilets. Further, to ensure easy and proper disposal of sewerage, many toilets in Sectors 1, 2 and 3 were connected to a central sewer network. During the Kumbh Mela 2019, $300 \mathrm{Kms}$. roads with chequeredplates, 1200 premium tents for tourists, Pandal with a capacity to accommodate 10000 people for mega program, 04 contemporary convention halls with state of art facilities for each zone, 22 pontoon bridges, public accommodation with the capacity of 20000 beds were made.

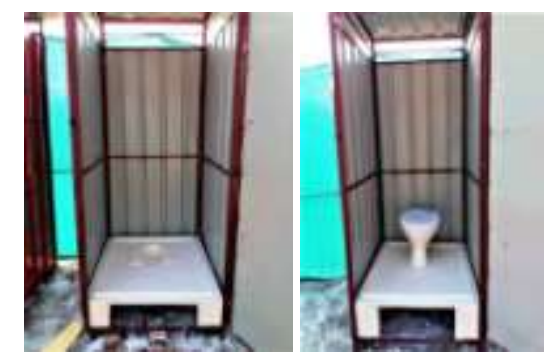

Figure 4: Toilet installed during Kumbh Mela

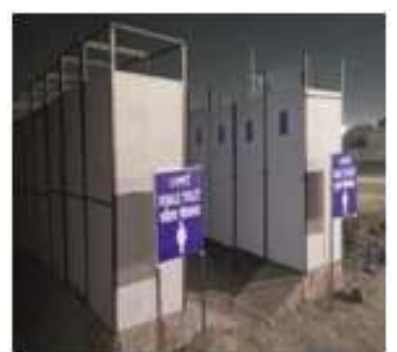

Figure 5: Toilet installed during Kumbh Mela (Source: Administrative report of Prayagraj Mela Authority)

\section{1) Solid waste Management}

Garbage bins were installed at every 25 - 50 meters all along different roads in vending areas, inside camps, near ghats (river banks), and circulation areas of the Mela. These bins had a liner bag, with strings attached to the edge so that the garbage collected could easily be contained in a carry bag shape and transported to tipper vehicles, with minimum chance of spill over. The solid waste management (SWM) plan was comprehensively designed with three layers of operation - starting from primary collection, to secondary collection and finally transportation for disposal at the Baswar Solid Waste Plant, which is operated and maintained by the Municipal Corporation, Prayagraj. For the sweeping of the streets and collection of waste from all camps, institutes and the Mela area, 650 gangs were deployed (12 sanitation workers in one gang) during the Mela period. A total of 120 tipper vehicles were circulated four to eight times a day along the Mela roads around routes dotted with garbage bins to collect garbage from all the 20 sectors. These tipper vehicles transferred the garbage bags to 40 compactors deployed in the Mela area [15]. The Flow of solid waste management is envisaged in figure 6.

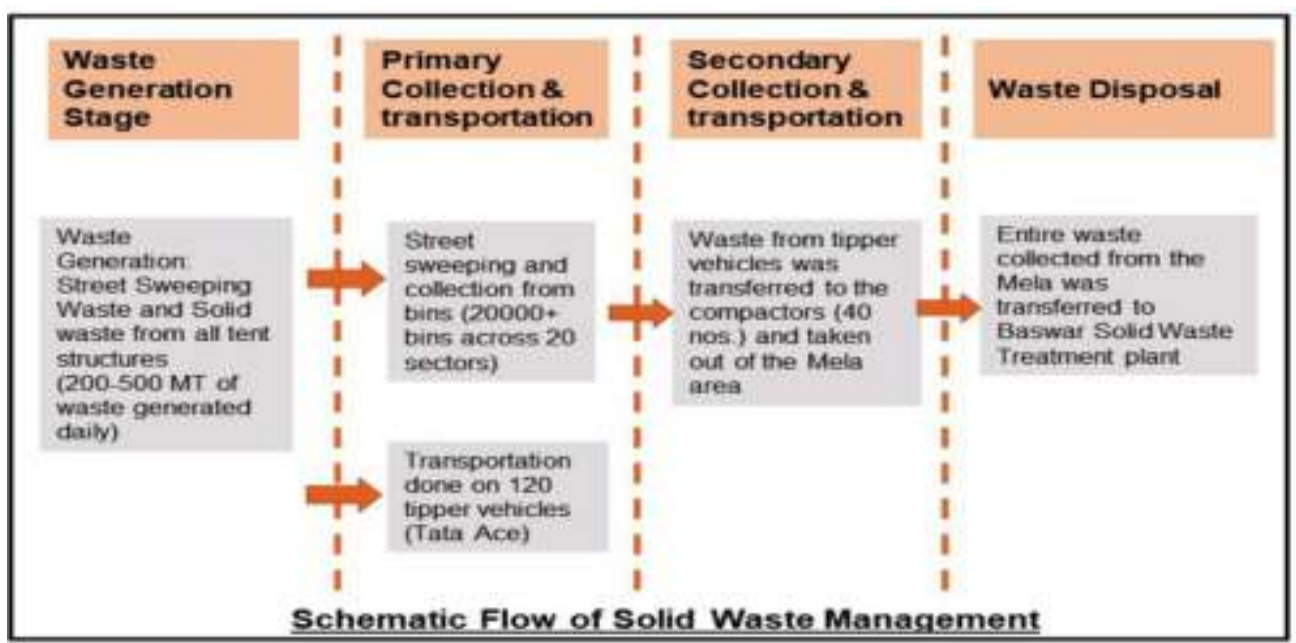

Figure 6: Schematic flow of Solid Waste Management

\section{2) Sewage management}

To prevent contamination of the river Ganga as well as the ground water, a well - orchestrated sewer network of 800+ $\mathrm{km}$ of unlined drains and $200+\mathrm{km}$ of piped drains was laid. More than 250 cesspool vehicles were hired to empty the septic tanks that were provided with all the toilets located within $200 \mathrm{ft}$ of the river bed. Collected sewage was treated at the existing sewage treatment plants (STPs) in the city and temporary bio - remediation plants set up in the Mela area. During the Kumbh Mela, sewage was collected through cesspool/suction vehicles. More than 2, 000 toilets in Sectors 1,2 and 3 were connected directly to the sewerage line. All the sludge collected from Sectors 1, 2, 3, 4, 5, 6, 7 and 8 and 18, 19 and 20 was transported to STPs at Rajapur, Salori and
Naini which were operated and maintained by the Ganga Pollution Control Unit (GPCU), Prayagraj [18]. Additionally, for sewage in Sectors 9, 10, 11, 12, 13, 14, 15, 16 and 17, two temporary geo - tube - based sludge treatment plants with a capacity of 2 MLD and 1 MLD respectively were installed by GPCU [19]. The suction of sludge from septic tanks and soak pits was performed round - the - clock during the Mela to cater to the large number of pilgrims and their usage of toilets and urinals. All the plants remained functional $24 X 7$ during the Mela period. The final effluent from these two geo - tube - based plants was transported to the nearest STP. The remaining $2 \%$ dry sludge was to be used as manure after lime treatment. The geo tubes were taken away by the agency to their factory for

Volume 10 Issue 10, October 2021 
further reuse. During the un installation phase, proper disposal of sludge from the septic tanks and soak pits was planned. Moreover, the pits were treated with bleach and Malathion, an organophosphate insecticide that neutralizes the chances of fleas breeding, and thus the outbreak of epidemic.

\section{3) ICT - based Monitoring of Sanitation Services}

ICT (Information and Communication technology) based monitoring ensured that the entire operation ran efficiently. A mobile application, customized in Hindi, was loaded on mobile devices. A QR code was assigned to each public toilet and this was fixed in each Public Toilet Complex (PTC). Swachhagrahis were trained to use the mobile app and mandated to give feedback twice a day. They visited PTCs, scanned the QR and provided feedback on each of the eight parameters of maintenance [20]. They also had the option of uploading photos and calling for action. An automated message was thus generated that would get passed on to the supervisor and vendor for necessary action. If not addressed by the next shift, the matter was escalated for remedy and vendors were penalized for non compliance. The following were the salient features of the ICT - based monitoring mechanism:

- Mobile - app based interface for easy access by volunteers.

- QR (Quick Response) coding of toilets [Fig.7].

- Periodic monitoring of the service level benchmarks for toilets and urinals.

- GPS - based vehicle tracking system for easy tracking of vehicles engaged in solid waste management.

- Centrally managed control room for feedback and response.

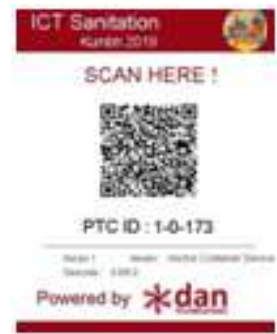

Figure 7: Monitoring of toilets through QR code (Source: Administrative report of Prayagraj Mela Authority)

\section{4) IEC (Information, Education and Communication) and BCC (Behavioral Change Communication) activities}

During the Kumbh Mela 2019, it was essential to bring about behavioral change and make sure the information about the sanitation facilities reached pilgrims coming to Kumbh. This was only possible by envisaging and executing rigorous outreach activities under Swachh Kumbh. Following are the list of activities that were undertaken to ensure the clear messaging of cleanliness and Clean Ganga through various mediums.

4.1 Paint My City Campaign: Spreading the message on Ganga conservation and sanitation during Kumbh Mela. Nearly 200, 000 sq. ft. area was painted with various themes of sanitation, cleanliness, and Ganga - basin conservation.
4.2 Ganga Sammelan: A national level conclave based on the theme of Ganga rejuvenation, conservation and protection of the river basin and protection of the Ganga biodiversity etc. was organized. This marked the participation of more than 5, 000 people raising their voice for Clean Ganga and making this issue visible during Kumbh Mela 2019.

\subsection{Swachhagrahis were deployed as sanitation} ambassadors for triggering and monitoring sanitation infrastructure and services. These 1, 500 Swachhagrahis worked as a major force to spread the message across all the 20 sectors in the Mela [21]

4.4 Information dissemination campaign was conducted through hoardings, banners, LED screens, pocket booklets, sanitation mascots etc. to promote cleanliness and sanitation in the Mela and spreading awareness on sanitation and Ganga conservation.

\section{5) Effective Resource Mobilization}

Budget of Rupees 234 Crore was sanctioned to allow fulfillment the objective of Swachh (Clean) Ganga, Swachh (Clean) Mela and Zero open defecation with adequate toilet facilities. A total of 20, 000 dustbins were proposed to be placed along the roads and Ghats, circulating areas and inside camps and vending areas. An unparalleled plan was put together to position dustbins in such a manner that no visitor had to walk more than 25 meters to toss the garbage. For effective collection and transportation of the garbage, 120 tippers (six in each of the 20 sectors) and 40 compactors were made operational in the Mela area. All the waste collected was sent to Baswar solid waste treatment plant to get scientifically treated and ensure zero disposal of waste into Ganga or within the Mela area. During Kumbh Mela 2019, a total of 9, 888 MT solid waste was collected and transported to the plant within the event's duration of 50 days.

\section{6) Medical facilities}

During the Kumbh Mela, 150 ambulances, 10motorized river ambulances, advanced life supply ambulances, 40 - bed trauma care facility and 1 air ambulance were deployed in the Mela area for emergency situations

\section{7) City Sanitation Management}

For the disposal of solid waste, Prayagraj Nagar Nigam had set up a solid waste plant in Baswar in 2012. Developed in an area spanning 62 acres, this plant processes the solid waste generated by the entire city. Altogether, 100 metric tonnes of solid waste gets processed in this plant per day, scientifically. Around 3, 300 safaikarmis (sanitation workers) and 90 safainayaks (Sanitation supervisors) have been appointed to keep various roads and lanes of all the 80 wards of the city clean. Around 27 port stations have been developed by Prayagraj Nagar Nigam from where solid waste is collected and taken to the plant for processing.

\section{8) Swachhagrahis: The Sanitation Volunteers}

It was strategically planned to deploy Swachhagrahis to monitor the cleaning activities for each toilet and urinal blocks in the Mela area during Kumbh Mela 2019 and simultaneously encourage pilgrims to use the sanitation 
infrastructure installed under Swachh Kumbh. To ensure an open defecation free Kumbh, the deployment of Swachhagrahis was essential and they played a vital role in the implementation of Swachh Kumbh initiatives. There were a total of 1, 500 Swachhagrahis from across the state engaged in the Kumbh Mela 2019.

Swachhagrahis are volunteers who were trained on sanitation issues and challenges. Prior to the Mela, intense training was imparted to each of these Swachhagrahis about the ways to monitor the operation and maintenance of the toilets deployed in the Mela. They used an ICT - based monitoring app managed through a handheld device where all the community toilets deployed in the Mela area were verified twice a day. This was purely technical, and based upon the reports generated every day, a mechanism was developed to inform and instruct the sanitation supervisors in the respective sector to address any issues raised by the system. Swachhagrahis were given a kit comprising items essential to operate in the field, which included jackets, whistles, water bottles etc. They were distinctly visible around the Mela, creating a buzz around proper usage and safeguarding of the sanitation infrastructure and services. In addition, there were 30 Ganga Praharis engaged in triggering activities by the Wildlife Institute of India under the National Mission for Clean Ganga's NamamiGange program. They were deployed at the ghat area and helped senior citizens reach nearby toilet blocks. The Ganga Task Force, also formed under the NamamiGange program, conducted awareness campaigns throughout the Mela period to inform and encourage pilgrims about the sanitation infrastructure and services provided by the Mela Authority.

\section{9) NamamiGange: A partner sanitation efforts}

NamamiGange, a flagship program of the National Mission for Clean Ganga, extensively supported the sanitation infrastructure and services during Kumbh Mela. It provided financial support for several initiatives viz. deployment of toilets, urinals, dustbins and also the bio - remediation of the 45 drains flowing towards the rivers Ganga and Yamuna.

\section{0) National Green Tribunal Recommendations}

Sanitation and waste management initiatives during the Kumbh Mela were closely monitored by a National Green Tribunal (NGT) which appointed monitoring and supervisory committee headed by Hon'ble Justice ArunTandon. The committee conducted several visits before, during, and post - Kumbh and interacted with all the key stakeholders about sewage management, waste water treatment, sludge disposal, bio - medical waste management and solid waste management initiatives for the Mela. The National Green Tribunal (NGT) has expressed following concerns over the solid waste that has accumulated in Prayagraj after the Kumbh Mela [22].

- Processing of un segregated solid waste at Baswar processing plant

- Certain incidences of waste water collection in pits.

- Bio - remediation of city drains flowing into Ganga.

- Sewage management through temporary STPs (Sewage Treatment plant) set up in the Mela area.

\section{Challenges and Suggestions}

- Timely procurement and fast - track issuance of apportioned funds are critical to efficiently execute the sanitation plan.

- Integrated tender for all toilets, including toilets within camps. This shall ensure that the accountability of O\&M remains with the vendor and execution happens without any ambiguity.

- Deployment of toilets should be done as per layout. Bulk deployment of toilet units at a single location can be avoided. Sewerage lines should be planned and deployed across all the sectors, wherever possible.

- Female toilets should be attended by female workers only. There should be enough incinerators for disposal of sanitary napkins to avoid choking. Early deployment of these volunteers would ensure improved training and sensitization.

- Odor management is very important and new organic methods should find out.

- Water logging/accumulation is challenge near the toilet units and it should have proper drainage.

- Identification of effective location for installations of Toilets and urinals.

- Cleaning on regular interval to make toilets and urinals neat and clean.

- Movement of sludge during crowd in the Mela through same road while occupying by pilgrimage

\section{Conclusions}

After completion of KumbhMela, there is a greater challenge for the healthcare system. The huge mass gatherings causes the number of health related problems and disposal of sewage and garbage and sometimes the water pollution. The focus should be on the assessment of diseases and capacity building of the city to cater the problems. Kumbh Mela 2019 made a good efforts in the sanitation management than earlier Kumbh Melas and number of toilets have been increased to prevent open defecation and made arrangement to tap the drains flowing into the rivers by innovative approaches. It also focussed on participation of volunteers, uses of Information and communication technology and behavioural change through various ways of communication but still itrequires a proper planning, coordinated efforts and optimum utilization of available resources for better sanitation management to strengthen healthcare system and saving rivers from being polluted. Over the years, recognizing the importance of water, sanitation, and hygiene in minimizing health risks, the government has taken substantial measures to improve water and sanitation but still there is lot to do.

\section{Declarations}

Funding There is no source of funding.

Conflicts of interest /Competing interest: The authors declare that they have no conflicts of interest.

Availability of data and material: Not applicable

Code availability Not applicable

Author's contributions: Not applicable 
Ethics approval: Not applicable

Consent for publication: Not applicable

Acknowledgements We are grateful to Prayagraj Mela Authority for allowing us to use its photographs, data and reports published in its various book and other documents in this review.

\section{References}

[1] https: //ich. unesco. org/en/Decisions/12. COM/11. b. 12

[2] Christians remain world's largest religious group, but they are declining in Europe $\mid$ Pew research center. https: //www.pewresearch. org/fact tank/2017/04/05/christians - remain - worlds - largest - religious - group - but - they - are - declining - in europe/. Accessed 26 Aug 2021.

[3] Christine N. Buzinde, Jyotsna M. Kalavar, NeenaKohli, David Manuel - Navarrete, Emic understandings of Kumbh Mela pilgrimage experiences, Annals of Tourism Research, Volume 49, 2014, Pages1 - 18, ISSN0160 - 7383, https: //doi. org/10.1016/j. annals.2014.08.001. (https: //www.sciencedirect.

com/science/article/pii/S0160738314000942)

[4] WHO. International travel and health, and mass gatherings. Available at: http: //www.who. int/ihr/ith_and_mass_gatherings/en/. [Last accessed 28.08.2021]

[5] Khan K, Sears J, Wei Hu V, Brownstein JS, Hay S, Kossowsky D, et al. Potential for the international spread of middle east respiratory syndrome in association with mass gatherings in Saudi Arabia. PLoS Current Outbreaks 2013. edition 1.

[6] PLoS Current Outbreaks 2013. edition 1., Olympic Planning Unit National School of Public Health Greece. Mass gatheings and public health: The experience of Athens 2004 Olympic games. Available at: http: //www.euro. who. int/_data/assets/pdf_file/ 0009/98415/E90712. pdf. [Last accessed 28.08.2021]

[7] Abubakar I, Gautret P, Brunette GW, Blumberg L, Johnson D, Poumerol G, et al. Gobal perspectives for prevention of infectious diseases associated with mass gatherings. Lancet Infect Dis 2012; 12: 66-74.

[8] Ahmed Q, Barbechi M, Memish ZA. The quest for public health security at Hajj: the WHO guidelines on communicable disease alert and response during mass gatherings. Travel Med Infect Dis J 2009; 7: 226-30.

[9] Memish ZA, Alrabeeah AA. Jeddah declaration on mass gatherings health. Lancet Infect Dis 2011; 11: 342-3. http: //dx. doi. org/10.1016/S1473 - 3099 (11) 70075 - 5

[10] Anand, Uttpal\&Srivastava, Motilal\& Ahmad, Sarfraz\&Sundaramurthy, Suresh \&Paliwal,. (2021). INVESTIGATION OVER WATER QUALITY OF RIVERS GANGA AND YAMUNA DURING KUMBH - 2019 - A CASE STUDY AT PRAYAGRAJ (ALLAHABAD), UTTAR PRADESH, INDIA.10.13140/RG.2.2.21847.60323.

[11] Sharma U, Desikachari BR, Sarma S. Protocol for development of a risk assessment tool for planning and management of religious mass - gathering events of India - a health system - strengthening initiative. Pilot Feasibility Stud.2019 Jun 24; 5: 83. doi: 10.1186/s40814 - 019 - 0464 - z. PMID: 31293791; PMCID: PMC6591856.

[12] https: //cag. gov. in/uploads/download_audit_report/2014/Uttar_Prades h_3_2014_chap_1.pdf

[13] Kumbh Mela Mapping the Ephemeral Mega - City GSD Urban India Project | Harvard University.

[14] Vortmann M, Balsari S, Holman SR, Greenough PG. Water, sanitation, and hygiene at the world's largest mass gathering. Curr Infect Dis Rep 2015; 17: 5. http: //dx. doi. org/10.1007/s11908 - 015 - 0461 - 1.

[15] https: //jalshakti - ddws. gov. in/sites/default/files/Annual_report_2018_19_dws. pdf Annual Report 2018 - 19 published by GOVERNMENT OF INDIA MINISTRY OF DRINKING WATER \& SANITATION (Since renamed as Department of Drinking Water and Sanitation, Ministry of Jal Shakti)

[16] https: //cag. gov. in/en/audit - report/details/9271; Report No.3 of 2014 - Report of the Comptroller and Auditor General of India on Performance Audit on Maha Kumbh Mela - 2013, Allahabad for the year ended 31 March 2013 government of Uttar Pradesh.

[17] https: //theprint. in/india/governance/2019 - kumbh mela - is - the - costliest - ever - with - a - budget - of - rs - 4200 - crore/178304/ (last assessed on 05 September 2021)

[18] https: //swachhindia. ndtv. com/kumbh - 2019 - this is - how - ganga - is - being - kept - clean - during the - kumbh - mela - 30323/Last assessed on 05 September 2021

[19] https: //smcg - up. org/2018/12/05/e - tender - for treatment - of - drains - by - modular - technology using - geo - tubes - for - kumbh - mela - 2019/ (last assessed on 05 September 2021)

[20] https: //www.bibliomed. org/mnsfulltext/218/218 1614622993. pdf?1630821162 (Last assessed on 05 September 2021)

[21] https: //swachhindia. ndtv. com/kumbh - mela - 2019 - swachh - bharat - mission - swachhta - doot - go extra - mile - to - ensure - cleanliness - 30297/ (Last assessed on 05 September 2021)

[22] 24. https: //www.hindustantimes. com/india news/alarmed - at - post - kumbh - mess - in prayagraj - ngt - warns - of - epidemic/story c0dhTgyoLsI7XpCbst91OP. html (Last assessed on 05 September 2021)

[23] Yamin M (2015) Health management in crowded events: Hajj and Kumbh. BIJIT - BVICAM's Int J InfTechnol 7 (1): 791-794

[24] Mishra, B., Baghel, A. S., Paliwal, D. et al. Study of Spiritual Health Determinants in Indian Saints (Sadhus) at Ujjain Kumbh Mela (Simhast) 2016. J Relig Health 59, 1233-1257 (2020). https: //doi. org/10.1007/s10943 - 019 - 00764 - 3

[25] http: //digibuo. uniovi. es/dspace/bitstream/10651/39115/6/TFM_MariaRodri guesLMdeAlmeida. pdf

[26] Kumbh Mela | Significance, Festival, \& History. In: Encycl. Br. https: //www.britannica. 
com/topic/Kumbh - Mela. Last assessed on 05 September 2021.

[27] Tewari S, Khan S, Hopkins N, Srinivasan N, ReicherS. Participation in Mass gatherings can benefit well - being: longitudinaland control data from a North Indian Hindu Pilgrimage Event. PLoS ONE.2012; 7: e47291.

[28] Barnett I, Khanna T, Onnela J - P. Social and spatial clustering of people at humanity's largest gathering. PLOS ONE.2016; 11: e0156794.

[29] Balsari S, Greenough PG, Kazi D, Heerboth A, Dwivedi S, Leaning J. Public health aspects of the world's largest mass gathering: The 2013 Kumbh Mela in Allahabad, India. J Public Health Policy.2016 Dec; 37 (4): 411 - 427. doi: 10.1057/s41271 - 016 0034 - z. PMID: 28202925.

[30] Dwivedi S, Cariappa MP. Mass - gathering Events: The Public Health Challenge of the Kumbh Mela 2013. Prehosp Disaster Med.2015 Dec; 30 (6): 621 4. doi: 10.1017/S1049023X15005245. Epub 2015 Oct 22. PMID: 26490181

Volume 10 Issue 10, October 2021 www.ijsr.net 